\title{
Detection of virulent Marek's disease virus in poultry in India
}

\author{
A. RAJA ${ }^{1}$, G. DHINAKAR RAJ ${ }^{1}$, P. BHUVANESWARI ${ }^{1}$, C. BALACHANDRAN ${ }^{2}$, K. KUMANAN $^{\prime}$ \\ ${ }^{1}$ Department of Animal Biotechnology, ${ }^{2}$ Department of Veterinary Pathology, Madras Veterinary College, \\ Chennai - 600007 , TN, India
}

Received January 13, 2009; accepted September 25, 2009

\begin{abstract}
Summary. - Marek's disease virus (MDV) isolated from poultry flocks in three states of India was monitored for the virus occurrence in the field. The MDV genome was isolated from feather follicles, spleen, and liver of the chicken (173 samples). Twenty two samples were positive for MDV genome in PCR and belonged to the serotype 1 . The sequencing of MEQ gene of 11 samples revealed that nucleotide sequences of the isolate Ind-KA-01-06 was similar to the very virulent MDV, strain RB-1B. In situ hybridization studies also confirmed a presence of MDV serotype 1 in the infected liver tissues. Furthermore, the ability of the virus to induce apoptosis detected by flow cytometry showed that the virulent MDV induced apoptosis more efficiently than Turkey herpesvirus (HVT) vaccine virus. The present study showed the presence of virulent/very virulent MDV strains in the Indian poultry flocks.
\end{abstract}

Keywords: Marek's disease virus; genotyping; in situ hybridization; flow cytometry

\section{Introduction}

MDV is a member of the family Herpesviridae and is allocated to the genus Mardivirus (Cantello et al., 1991, van Regenmortel et al., 1999). Based on its virulence for chicken, its ability to induce T-cell lymphomas and antigenic properties, there are 3 serotypes of MDV, serotype 1 (MDV-1), serotype 2 (MDV-2), and serotype 3 (MDV-3) (Payne, 1985; Schat, 1985). Virulent strains of MDV have been categorized according to the protection indices and lesion scores in unvaccinated, HVT-vaccinated or bivalently vaccinated (HVT/SB-1) chickens (Witter, 1983). The pathotypes described by these analyses represent a continuum, but have been generally classified as mildly virulent (mMDV), virulent (vMDV), very virulent (vvMDV) and very virulent plus (vv+MDV) (Witter, 1997b). Although these classifica-

E-mail: raja@tanuvas.org.in; fax: +9144-25369301.

Abbreviations: $\mathrm{CEF}=$ chicken embryo fibroblast; $\mathrm{DEF}=$ duck embryo fibroblast; HVT = Turkey herpesvirus; MD = Marek's disease; $\mathrm{MDV}=$ Marek's disease virus; p.i. = post infection; $\mathrm{vMDV}$ = virulent MDV; vvMDV = very virulent $\mathrm{MDV}$ tions describe a continuum of virulence from a field perspective, it is important to note that the distinctive lesions appear to be associated with the vVMDV (high incidence of visceral lesions) and vv+MDV (high incidence of stunting, neurologic lesions and rapid transmission rate) pathotypes (Rosenberger et al., 1997; Gimeno et al., 1999). Moreover, the diagnosis of MD is problematic because the pathology induced is rarely pathognomonic. The affected birds may harbor both vaccinal and wild strains of MDV and detection of non-vaccinal MDV is not necessarily associated with tumor formation and disease (Silva and Witter, 1996). Usually, a clinical MD diagnosis is based on gross and microscopic lesions together with the isolation and identification of MDV from infected tissues (Sharma, 1985). The virus isolation is usually performed by virus propagation in cell culture and identification/quantification of the virus by cytopathic changes (plaque formation) or by identification of infected cells by immunostaining (De Laney et al., 1998). In recent years PCR has emerged as an additional diagnostic tool offering an advantage of serotype specificity (Davidson et al., 1995; Walkden-Brown et al., 2001). Moreover, PCR has the ability to differentiate between vaccinal and field strains of MDV (Handberg et al., 2001). Sequence analysis of different MDV pathotypes revealed that they displayed 
differences in sequence of some specific genes like MEQ gene (Laurent et al., 2004).

MD is controlled by the vaccination and good management practices (Calnek and Witter, 1991). Naturally occurring nonpathogenic strains of MDV-1, MDV-2, and HVT have been used individually or together in bivalent vaccines (Hirai et al., 1986). In India, the HVT-FC126 (serotype 3) or MDV strain SB-1 (serotype 2) are used as the individual vaccines to combat MD. Recently, a high mortality and morbidity with suggestive lesions of MD have been reported from several farms in India. The aim of the present study was to investigate the presence and features of the causative agent.

\section{Materials and Methods}

Collection of samples. A total of 173 samples were collected from poultry farms in 3 states in India - Tamil Nadu, Karnataka, and Maharastra (Table 1). Blood, feathers and organs (liver and spleen) were collected and processed in formalin or kept on ice. The formalin fixed samples were used for histopathology and the ice samples were used for the virus isolation. Necropsy was conducted for the dead birds as well as for ailing birds.

DNA extraction. The total DNA from blood, feather tips and organs was extracted. In brief, the samples were mixed with proteinase $\mathrm{K}$ mixture and incubated at $55^{\circ} \mathrm{C}$ overnight with shaking. Next day, $5 \mathrm{~mol} / \mathrm{l}$ sodium acetate and phenol/chloroform/isoamylalcohol mixture were added and centrifuged. To the aqueous phase, isopropanol was added to precipitate DNA. The air-dried DNA pellet was dissolved in nuclease-free water and stored at $-20^{\circ} \mathrm{C}$ until use (Handberg et al., 2001).

Detection of MDV genome by PCR. The samples were subjected to PCR with primers specific to the partial sequence of MEQ gene located in the long terminal repeat region (Liu and Kung, 2000). The MEQ gene fragment was amplified by the following primers: MEQ FP 5'-GGA TCG CCC ACC ACG ATT ACT ACC-3' and MEQ RP 5'-ACT GCC TCA CAC AAC CTC ATC TCC-3'. The
PCR conditions were as follows, $10 \mu \mathrm{l} 2 \mathrm{x}$ PCR Master mix, $10 \mathrm{pmol}$ MEQ FP, 10 pmol MEQ RP, $3 \mu$ DNA template, and sterile distilled water to $20 \mu$ l. After mixing the contents, the PCR was performed by applying 35 cycles of $94^{\circ} \mathrm{C}$ for $1 \mathrm{~min}, 58^{\circ} \mathrm{C}$ for $1 \mathrm{~min}$ and $72^{\circ} \mathrm{C}$ for $1 \mathrm{~min}$ with initial denaturation at $94^{\circ} \mathrm{C}$ for $5 \mathrm{mins}$ and a final extension at $72^{\circ} \mathrm{C}$ for 7 mins. The samples were analyzed by $2 \%$ agarose gel electrophoresis using ethidium bromide. The samples positive for MEQ gene produced $400 \mathrm{bp}$ amplicon.

Sequencing $M E Q$ gene amplicons and sequence analysis. The samples that amplified MEQ gene specific amplicon (400 bp) were used to make bulk PCR product $(100 \mu \mathrm{l})$ with $P f u$ DNA polymerase. Then these products were gel purified using $\mathrm{M} / \mathrm{s}$ Gel purification kit (Invitrogen) and sequenced by automated sequencer ABI genetic analyzer using $\mathrm{ABI}$ cycle sequencing kit. Obtained sequences were aligned with MEQ gene sequence of MDV strains available in the GenBank using CLUSTAL-W 2.0 program. The phylogenetic tree was constructed by using MEGA 4.0 program. The MEQ gene sequence similarities of examined samples with the corresponding sequences of reference strains 571-DQ534531; 637-AY362713; 686-AY362727; L strain-AY362717; RB1B-EF523390; 549aDQ534530; 573-AY362711; 643P-AY362716; CU2-DQ534537; Md11-AY510475; 567-AY362709; 595-AY362715; 648-AY362725; CVI988-DQ534538; N strain-AY362718; RL strain-AY362720 were estimated by using DNA STAR program.

In situ hybridization. The 400 bp MEQ gene specific primers were used to generate digoxigenin (dig) labeled probes by using PCR dig labeling kit (Roche). The liver sections were prepared on silane treated glass slides. After de-paraffinization and re-hydration, $4 \mu \mathrm{m}$ tissue sections were treated with proteinase $\mathrm{K}$ and incubated with a hybridization cocktail containing $50 \mu \mathrm{g} / \mathrm{ml} \mathrm{dig-labeled} \mathrm{probe.}$ Hybridization was done at $45^{\circ} \mathrm{C}$ in a humid chamber overnight. After blocking with normal bovine serum (1:100 dilution), sections were treated with rabbit anti-dig antibodies conjugated with $\operatorname{HRP}(1: 500)$ (DAKO) for $2 \mathrm{hrs}$ at room temperature and the reaction product was stained by diaminobenzidine (Sigma). The section was then counterstained with neutral red and mounted for visualization.

Virus isolation. For initial isolation of MDV field viruses, duck embryo fibroblast cells (DEF) were used. Further, MDV-infected

Table 1. Characteristics of samples collected from chicken for isolation of MDV

\begin{tabular}{|c|c|c|c|c|c|c|c|c|c|}
\hline \multirow{2}{*}{$\begin{array}{l}\text { Place of sample } \\
\text { collection }\end{array}$} & \multirow{2}{*}{$\begin{array}{l}\text { Age of the } \\
\text { birds } \\
\text { (in weeks) }\end{array}$} & \multirow[t]{2}{*}{ Flock size } & \multirow{2}{*}{$\begin{array}{l}\text { Total mor- } \\
\text { tality } \\
(\%)\end{array}$} & \multicolumn{3}{|c|}{ Number of sample collected } & \multicolumn{3}{|c|}{ Number of sample positive in PCR } \\
\hline & & & & Blood & Feathers & $\begin{array}{l}\text { Spleen and } \\
\text { liver }\end{array}$ & Blood & Feathers & $\begin{array}{l}\text { Spleen and } \\
\text { liver }\end{array}$ \\
\hline \multirow[t]{4}{*}{ Karnataka } & 10 & 25,000 & 12 & 11 & 46 & 7 & 2 & 8 & 2 \\
\hline & 24 & 25,000 & 8 & & & & & & \\
\hline & 36 & 25,000 & 6 & & & & & & \\
\hline & 52 & 25,000 & 10 & & & & & & \\
\hline \multirow[t]{4}{*}{ Tamil nadu } & 30 & 40,000 & 15 & 24 & 30 & 2 & 4 & 5 & 1 \\
\hline & 38 & 30,000 & 5 & & & & & & \\
\hline & 40 & 30,000 & 6 & & & & & & \\
\hline & 42 & 25,000 & 9 & & & & & & \\
\hline \multirow[t]{2}{*}{ Maharastra } & 24 & NA & NA & 28 & 25 & - & - & - & - \\
\hline & 28 & & & & & & & & \\
\hline Total & & & & & & 173 & & & 22 \\
\hline
\end{tabular}


DEF cells were serially passaged in chicken embryo fibroblast (CEF) primary cells grown in DMEM supplemented with $10 \%$ bovine serum and maintained at $37^{\circ} \mathrm{C}$. Buffy coat cells positive for MEQ gene by PCR (isolates Ind-KA-01-06, Ind-KA-02-06 and Ind-KA-03-06) were used for isolation of MDV in cell culture. The isolates were serially passaged in CEF for 5 passages. The infected cells were observed daily for the appearance of cytopathic effect (CPE) characteristics of MDV.

Detection of apoptosis by flow cytometry. The field isolate IndKA-01-06 and HVT ( $3 \mathrm{ml}$ each) were used for infection of CEF cells grown in $25 \mathrm{~cm}^{2}$ tissue culture flasks. Non-infected CEF cells were used as control. At 24, 48, and $72 \mathrm{hrs}$ post infection (p.i.), the cells were harvested by $0.1 \%$ trypsin, washed with cold PBS, and $1 \mathrm{x}$ $10^{6}$ cells $/ \mathrm{ml}$ were taken for further analysis. The cells were treated with $0.9 \%$ sodium chloride, followed with $90 \%$ ethanol. After the incubation of 30 mins at room temperature, the cells were treated with propidium iodide ( $10 \mu \mathrm{g}$ final concentration) and RNAse. At the end of incubation, the samples were run in the flow cytometer (FACSCalibur, Beckton Dickinson) to assess the level of apoptosis induced by field virus-infected and HVT-infected CEF cells at 24, 48, and $72 \mathrm{hrs}$ p.i. The samples were examined in triplicates for each time point indicated.

\section{Results}

\section{Histopathology of MDV-affected birds}

Liver and spleen tissues from the dead birds collected in formalin were processed for histopathology examination. The tissues showed extensive infiltration of pleomorphic lymphocytes in both tissues suggestive of MD (Fig. 1). Furthermore, MDV genome was identified in the pleomorphic lymphocytes in the liver tissues as dark brown spots using in situ hybridization analysis (Fig. 2).

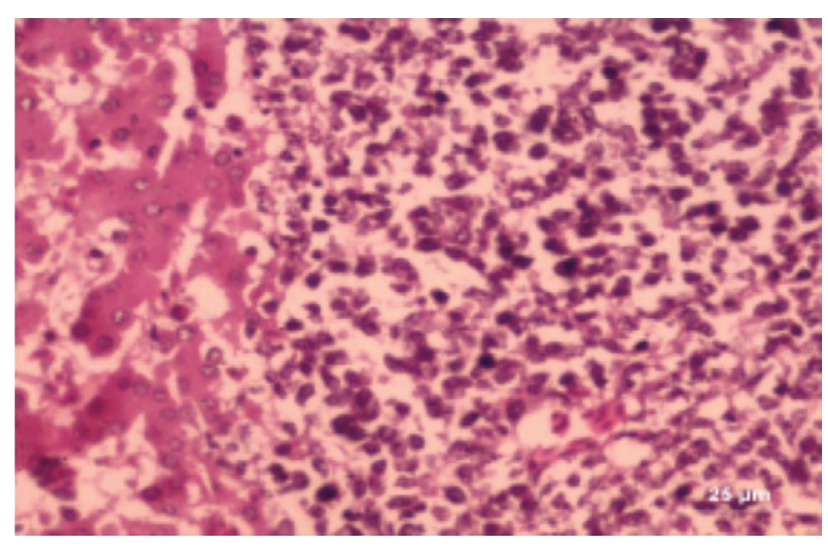

Fig. 1

Histopathology of liver tissue from MD-affected bird

Infiltration of pleomorphic lymphocytes (magnification 40x), hematoxylin/eosin staining.

\section{Detection of MDV genome by PCR}

MDV DNA in mixture with total DNA isolated from different samples was subjected to PCR analysis. MDV-1 specific PCR product of about 400 bp was detected in 22 samples out of 173 samples tested. Thirteen positive samples were shown in Fig. 3.

\section{Sequence analysis of MDV field isolates}

From the 22 positive samples containing MEQ gene, 11 samples were sequenced and submitted to the GenBank. The sequence analysis showed 89.2 to $100 \%$ nucleotide sequence homology among the field isolates for MEQ gene. The phylogenetic analysis showed that the field isolate Ind/KA01/06 grouped to the reference strain RB-1B with nucleotide sequence homology of $95.3 \%$ with this strain. However, the rest of isolates Ind/KA02/06, Ind/TN02/07, Ind/TN03/07, Ind/TN04/07, Ind/TN05/07, Ind/TN06/07, Ind/TN07/07, Ind/TN09/07, Ind/TN10/07 and Ind/TN11/07 grouped with strains 571, 637, 686, L strain, 549a, 573, 643P, CU2, Md11, 567, 595, 648, CVI988, N strain, and RL strain as they displayed nucleotide sequence homology of 91 to $99 \%$ (Fig. 4). The deduced amino acids sequence of the field isolates also showed that the isolate Ind-KA01/06 had a similar amino acid sequence with the reference strain RB-1B.

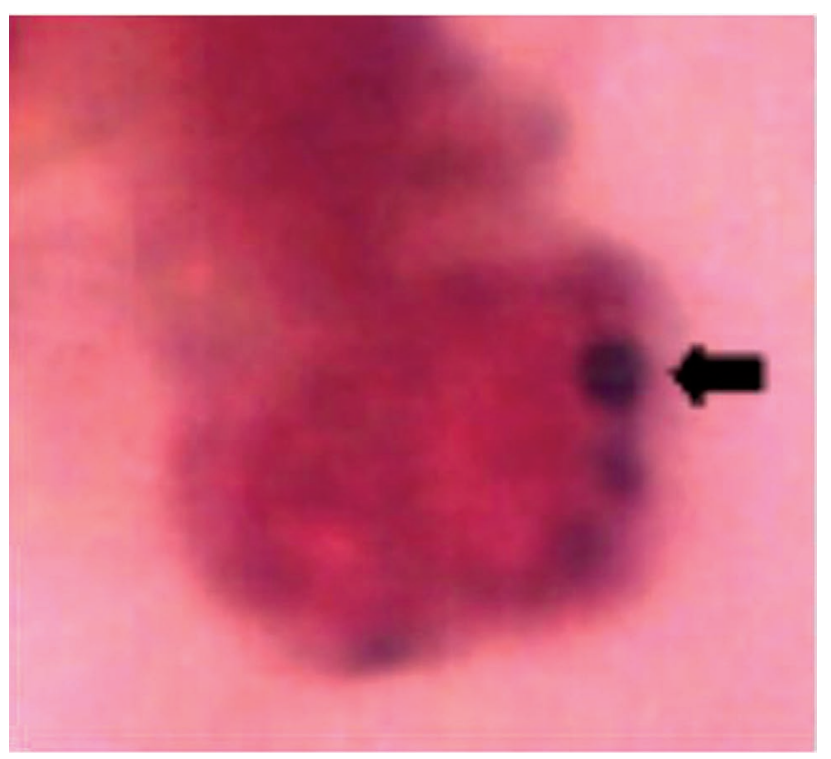

Fig. 2

Inclusions in the cytoplasm of lymphocytes in liver tissue from MD-affected bird detected by in situ hybridization

Magnification 100x, hematoxylin/eosin staining. 


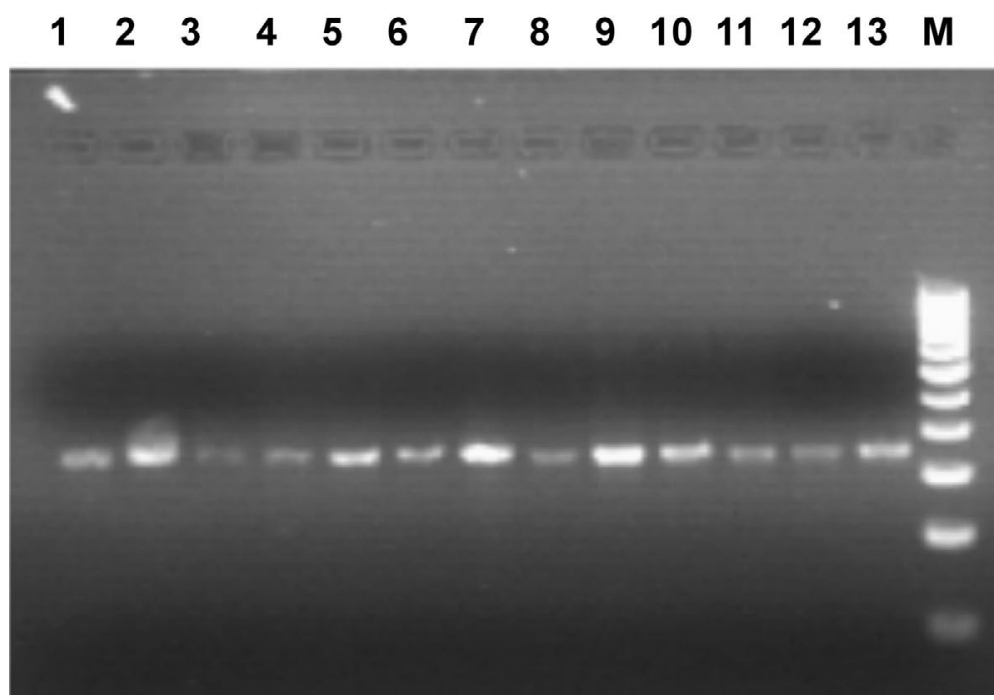

Fig. 3

PCR amplification of Meq gene of MDV field isolates

Ind-KA01-06 (lane 1); Ind-KA02-06 (lane 2); Ind-KA03-06 (lane 3); Ind-TN01-06 (lane 4); Ind-TN02-07 (lane 5); Ind-TN02-07 (lane 6); Ind-TN03-07 (lane 7); Ind-TN04-07 (lane 8). Ind-TN07-07 (lane 9); Ind-TN08-07 (lane 10); Ind-KA01CC-06 (lane 11); Ind-TN05-07 (lane 12); Ind-TN06-07 (lane 13); 100 bp ladder (lane M);

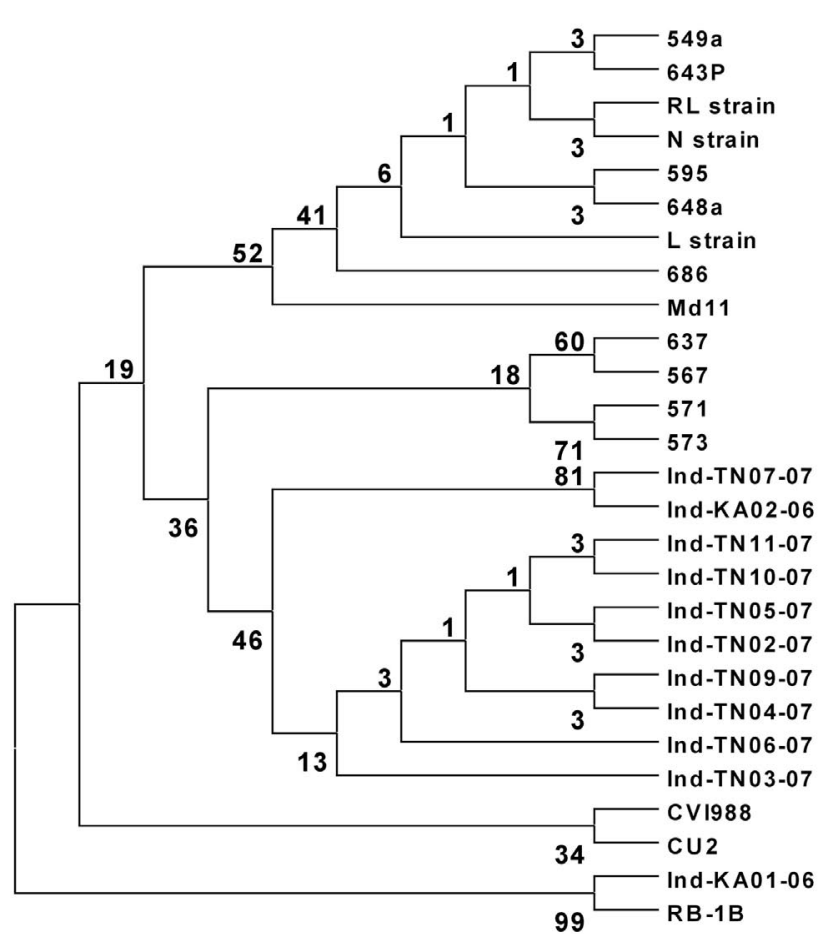

Fig. 4

Phylogenetic analysis of MDV field isolates using Mega program

\section{Isolation of MDV in cell culture}

Ind-KA-01-06 and Ind-KA-02-06-infected CEF cells showed CPE between day 5 and 7 p.i. The CPE included appearance of rounded refractile cells and after prolonged incubation each plaque was surrounded by the additional refractile cells at periphery. Over prolonged infection, the plaques developed clear areas in the centre (results not shown).

\section{Level of apoptosis induced by MDV field isolates in CEF}

At $24 \mathrm{hrs}$ p.i., the average apoptosis induced for the uninfected cells was $2.2 \%$, whereas for the field MDV-infected cells $5.3 \%$ and for the vaccine HVT-infected cells $3.8 \%$. At $48 \mathrm{hrs}$ p.i., the average apoptosis induced for the uninfected cells was $8.6 \%$, whereas for the field MDV-infected cells $11.6 \%$ and for the vaccine HVT-infected cells $11.2 \%$. At 72 hrs p.i., the average apoptosis induced for the uninfected cells was $19.2 \%$, whereas the for the field MDV-infected cells $40.2 \%$ and for the vaccine virus HVT $27.7 \%$.

\section{Discussion}

The principal objective of this paper was to identify the MDV circulating in India, since outbreaks of the MD were 
recorded in several layer farms in different states of India in spite of regular vaccination at hatchery level. We tried to identify the causative agent by molecular technique like PCR and in situ hybridization, to type the viral genome of MDV prevalent in India, to isolate the virus by cell culture techniques, and finally to assess the virulence of MDV by the flow cytometry.

The histopathological studies revealed the presence of pleomorphic lymphocytes in the liver sections suggestive of MD (Calnek and Witter, 1991). In the present study, necropsy of dead and ailing birds showed a development of tumors in liver and spleen in the age groups of 10-52 weeks.

The recent publication of the complete genome sequences for all three serotypes of MDV provided researchers with the information required to develop highly specific PCR for two isolates of serotype 1, GA strain (Lee et al., 2000a) and Md5 strain (Tulman et al., 2000). Single sequences for serotype 3 (Afonso et al., 2001) and serotype 2 (Izumiya et al., 2001) have given researchers the data required for development of a highly specific PCR. In addition, it is now possible to compare the genomes of two MDV-1 isolates to look for exploitable sequence differences. The PCR analysis showed that out of the 173 samples tested, 22 samples were positive for the amplification of the unique MEQ gene of MDV (Liu and Kung, 2000) responsible for a formation of liver and spleen tumors. The MEQ gene of MDV-1 encodes a protein that contains transactivating domains and a basic leucine zipper domain (Qian et al., 1995; Liu et al., 1998). A 178 bp insertion in the MEQ transactivating domain was reported to be specific for CVI 988 vaccine strain (Lee et al., 2000b) and could possibly be useful in a differentiating between the vaccine and field strains in vaccinated birds. The CVI 988 vaccine virus had two distinct copies of MEQ gene and whereas one copy contains the insert, the second one remains in its original form (Lee et al., 2000). The amplification of the complete ORF of MEQ gene of the field isolates showed only one band and confirmed that these isolates belonged to the wild type MDV-1 rather than to vaccine virus CVI 988 that is not used in India.

The phylogenetic analysis of MEQ gene of the field MDV isolates showed that the isolate Ind-KA-01-06 grouped with the vvMDV strain RB-1B. Since the nucleotide sequence homology with the isolate Ind-KA-01-06 was $95.3 \%$, the other field isolates belonged to the vMDV pathotype, as they had nucleotide sequence homology of 91-99\% with the vMDV reference strains such as $637,567,571$, and 573 .

The objective of the in situ hybridization study was to show that the tumor samples collected from the ailing and dead birds harbored a MDV belonging to the oncogenic serotype 1 . The results showed that the infected pleomorphic lymphocytes and liver cells showed the presence of MDV inclusion bodies in the cytoplasm. The MDV inclusion bodies have been reported to be present both in the cytoplasm as well as in the nucleus of infected cells (Calnek and Witter, 1991). To show the nuclear viral inclusion bodies by in situ hybridization, the probe should be less than $100 \mathrm{bp}$ (Nuovo, 2007). In our study, we used a 400 bp probe, what could be a cause for the low detection level of nuclear viral inclusion bodies.

The primary method for the diagnosis of MDV represents virus isolation in chicken kidney cells, DEF or CEF. Field strains of MDV-1 are generally isolated using chicken kidney and DEF cultures, while CEF culture is very useful for the serotype 2 and HVT isolation. Typically, MDV plaques develop in cell culture at 5-14 days p.i. However, it requires skilled technical persons to differentiate and identify the plaques produced by different serotypes. Hence, to differentiate between the virulence of MDV-1 and HVT, we used a flow cytometry for detection of the level of apoptosis induced by these viruses. The results clearly indicated that there was a difference in the level of apoptosis induced by the field MDV and by HVT. Hence, the flow cytometry could be an ideal tool for assessment of the MDV virulence based on its ability to induce apoptosis in primary cells. The use of conventional methods for this purpose is time-consuming and difficult.

The present study showed the presence of v/vvMDV-1 genome in poultry farms in India.

Acknowledgement. This work was supported by the grant from the Indian Council of Agricultural Research, Government of India, New Delhi under the Niche area of excellence in Animal Biotechnology.

\section{References}

Afonso CL, Tulman ER, Lu Z, Zsak L, Rock DL, Kutish GF (2001): The genome of turkey herpes virus. J. Virol. 75, 971-978. doi:10.1128/JVI.75.2.971-978.2001

Calnek, BW, Witter, RL (1991): Marek's disease virus. In Calnek BW, Barnes HJ, Beard CW, Yoder Jr HW (Eds): Disease of Poultry. 9th ed., Iowa State University Press, Ames, Iowa, pp. 342-385.

Cantello JL., Anderson AS, Francesconi A, Morgan RW (1991): Isolation of a Marek's disease virus (MDV) recombinant containing the lacZ gene of Escherichia coli stably inserted within the MDV US2 gene. J. Virol. 65, 1584-1588.

Davidson I, Borowsky A, Perl S, Malkinson M (1995): Use of the polymerase chain reaction for the diagnosis of natural infection of chickens and turkeys with Marek's disease virus and reticuloendotheliosis virus. Avian Pathol. 24, 69-94. doi:10.1080/03079459508419050

De Laney DB, Morrow CJ, Read KM, Tannock GA (1998): The development and evaluation of two tissue culture-grown Marek's disease challenge viruses. Avian Pathol. 27, 472-477. doi:10.1080/03079459808419371 
Gimeno IM, Witter RL, Reed WM (1999): Four distinct neurologic syndromes in Marek's disease: effect of viral strain and pathotype. Avian Dis. 43, 721-737. doi:10.2307/1592741

Handberg KJ, Nielsen OL, Jorgensen PH (2001): The use of serotype 1 - and serotype 3 -specific polymerase chain reaction for the detection of Marek's disease virus in chickens. Avian Pathol. 30, 243-249. doi:10.1080/ $\underline{03079450120054659}$

Hirai K, Nakajima K, Ikuta K, Kirisawa R, Kawakami Y, Mikami T, Kato S (1986): Similarities and dissimilarities in the structure and expression of viral genomes of various virus strains immunologically related to Marek's disease virus. Arch. Virol. 89, 113-130. doi:10.1007/BF01309883

Izumiya Y, Jang H-K, Ono M, Mikami T (2001): A complete genomic DNA sequence of Marek's disease virus type 2, strain HPRS24. Curr. Top. Micrbiol. Immunol. 255, 191-221.

Laurent S, Esnault E, Rasscharet D (2004): Single-nucleotide polymorphisms in two Marek's disease virus genes (Meq and gD): application to a retrospective molecular epidemiology study (1982-1999) in France. J. Gen. Virol. 85, 1387-1392. doi:10.1099/vir.0.79782-0

Lee LF, Wu P, Sui D, Ren D, Kamil J, Kung HJ, Witter R.L (2000a): The complete unique long sequence and the overall genomic organization of the GA strain of Marek's disease virus. Proc. Natl. Acad. Sci. USA 97, 6091-6096. doi:10.1073/pnas.97.11.6091

Lee SI, Takagi M, Ohashi K, Sugimoto C, Onuma M (2000): Difference in the meq gene between oncogenic and attenuated strains of Marek's disease virus serotype 1. J. Vet. Med. Sci. 62, 287-292. doi:10.1292/jvms.62.287

Liu JL, Kung HJ (2000): Marek's disease herpesvirus transforming protein MEQ: a c-Jun analogue with an alternative life style. Virus Genes 21, 51-64. doi:10.1023/ A:1008132313289

Liu JL, Ye Y, Lee LF, Kung HJ (1998): Transforming potential of the herpesvirus oncoprotein MEQ: morphological transformation, serum-independent growth, and inhibition of apoptosis. J. Virol. 72, 388-395.

Nuovo GJ (2007): The utility of in situ-based methodologies including in situ polymerase chain reaction for the diagnosis and study of viral infections. Human Pathol. 38, 1123-1136. doi:10.1016/j.humpath.2007.04.005

Qian Z, Brunovskis P, Rauscher F, Lee L, Kung HJ (1995): Transactivation activity of Meq, a Marek's disease herpes virus
bZIP protein presently expressed in latently infected transformed T cells. J. Virol. 69, 4037-4044.

Payne LN (1985): Pathology. In Payne LN (Ed.): Marek's Disease. Kluwer Academic Publishers, Hingham, Mass, pp. 43-76.

Rosenberger,JK, Cloud SS, Olmeda-Miro N (1997). Epizootiology and adult transmission of Marek's disease. Paper Presented at the Avian Tumor Virus Symposium, Reno, NV, 21 July 1997.

Schat, KA (1985): Characteristics of the virus. In Payne LN (Ed.): Marek's Disease. Kluwer Academic Publishers, Hingham, Mass, pp. 77-112.

Sharma JM (1985): Laboratory diagnosis. In Payne LN (Ed.): Marek's Disease - Scientific Basis and Methods of Control. Kluwer Academic Publishers, Hingham, Mass, pp. 151-175.

Silva RF, Witter RL (1996): Correlation for PCR detection of MDV with the appearance of histological lesions. Current Research in Marek's Disease, Proceedings of the 5th International Symposium on Marek'sDisease, 7-11 September 1996, pp. 302-307.

Tulman ER, Afonso CL, Lu Z, Zsak L, Rock DL, Kutish, GF (2000): The genome of a very virulent Marek's disease virus. J. Virol. 74, 7980-7988. doi:10.1128/JVI.74.17.79807988.2000

van Regenmortel MHV, Fauquet CM, Bishop DHL, Carstens E, Estes MK, Lemon S, Maniloff S, Mayo MA, McGeoch D, Pringle CR Wickner RB (Ed.): (1999): Virus Taxonomy. Seventh Report of the International Committee on Taxonomy of Viruses. Academic Press, New York, N.Y.

Walkden-Brown SW, Islam AFMF, Burgess SK, Wong CW, Groves PJ, Young PL, Cipriari T, Mastorakos Z, Tannock GA (2001): Comparison of PCR and virus isolation for detection of MDV viraemia following artificial and natural challenge in broiler chicks with homologous antibody. In Current Progress in Marek's Disease Research. Kennett Square, PA, American Association of Avian Pathologists.

Witter RL (1983): Characteristics of Marek's disease viruses isolated from vaccinated commercial chicken flocks: association of viral pathotype with lymphoma frequency. Avian Dis. 27, 113-132. doi:10.2307/1590377

Witter RL (1997b): Increased virulence of Marek's disease virus field isolates. Avian Dis. 41, 149-163. doi:10.2307/ $\underline{1592455}$ 